\title{
The Systematic Goal of Human Development: Individual Freedom Should Not Conflict with the Global Interest
}

\author{
Huiyi Tang \\ Harbin Institute of Technology, Heilongjiang 150001, China
}

\begin{abstract}
This paper calls for improving the world governance system in order to systematically solve the urgent human facing problems, such as mass-destructive weapons, climate change, ecological system deterioration, environmental pollution, food shortage, epidemic disease control, population planning, poverty elimination, etc.. It requires the formulation of goal system, road map and time table for the all over resolution of these urgent problems. It stresses the principle of individual freedom should not conflict with the global human interests. It requires the big powers cooperate with each other and unite with all nations and help improving the governance capability of the United Nation as a world government.

Index Terms - world governance, urgent human facing problems, global interests of human being, individual freedom, big powers cooperation.
\end{abstract}

\section{What End is Human Aiming for?}

The current state of the development of high-intelligent life on earth is highly ironical: on the one hand, science and technology highly and rapidly developed, and such high-intelligent life as known in the universe is yet unique; on the other hand, the mass-destructive weapons currently had been rapidly developed to an extend of capability of destroying the earth by thousands of times! What ultimate end is the mad behavior of human being aiming for? Where does the origin of this insanity lie?

\section{The Lesson of Two World Wars}

In review of the lesson of the two world wars, it is all because that some nations fight for hegemonism, in order to press and slave other nations. With regard to the economic development, the free competition of market economy developed to the Neo-Liberalism of monopoly capital. This "freedom" including developing arms industry, manufacturing mass destructive and high-speed global attacking weapons, selling arms, in order to seize monopoly profit, and hence caused the global arms contest.

After World War 2, the United Nation was established, in order to protect world peace and to prevent the reenact of the tragedy of human self-massacre. However, after World War 2, the local wars didn't stop, the origin of war didn't yet be eliminated. Up to now, it is still quite difficult in negotiations on global interests issues.

\section{Individual Freedom Should Not Conflict with Global Interests}

One of general world value upheld by human being is "freedom". However, "freedom" is not an absolute concept, it is actually limited at everywhere. while certain individual freedom harmed somebody else 's freedom or the global human interests, then such freedom has to be limited. This is virtually a simple principle. As the ancient Chinese Confucian doctrine goes: "Don't impose on others with whatever oneself does not desire." However, it seems quite difficult to be understood by modern human being — the unique high-intelligent life being in the universe!

\section{Improving the World Governance and Big Powers Cooperation}

The emergence and development of human being on earth had been probably over 3 million years which compares with the age of earth valued only 0.7 thousandth. However, the development of mankind is now at a critical moment of life and death. This is not the willingness of God, but formed by the evil of mankind itself. If mankind can sustainably develope forever, is determined by our global governance capability and level, that is, if it can realize the systematic goal of human development.[1,2]

Following the development of modern science and technology, now the world had been formed as a global village of closely linked, mutual relied and mutual helped in the same plight. Any nation, any group, if still be concerned only for its own interests and hegemonism, would be extremely foolish, and also not allowed by the global governance.

The next year is the 70th anniversary of the end of World War 2. Let us seize this opportunity to research on improving the global governance system and governance capacity in concern with its modernization and high efficiency. The time left for us by God is not much. If the problem could not be solved well enough, perhaps our next descendant would face some sort of fatal disasters.

The situation must be put under control. We hope that the United Nation can work as a world government to lead the systematic research and negotiation as well as implementation on global humanity issues.

All urgent and kernel human facing problems must be deeply studied and discussed, and adopt effective measures to seek for resolution. In which the big powers must shoulder their responsibility. They must cooperate with each other and unite with all nations and help improving the governance capability of the United Nation.

\section{All People Unite for the Final Struggle}

The mankind must formulate the road map and time table for eliminating mass destructive weapons and high-speed attacking weapons.

With regard to every sort of human facing urgent problems, 
such as climate change, ecological system deterioration, environmental pollution, food shortage, population planning, epidemic diseases control, poverty elimination, etc., must formulate relevant goal system, road map and time table for all over resolution.

The international judicial system has to be examined and consummated all over. All anti-human and war criminals must be brought to justice.

All sort of civilization systems and religion systems of the world, unite! To fight for the realization of human common goals.

This is the final struggle, unite! For tomorrow!

\section{References}

[1] Qian Xuesen, Key of Wisdom: On System Science Shanghai, Jiaotong University Press, 2005.

[2] Tang Huiyi, Systematology: Basic Theory for Scientific Development of Social System Shanghai, Jiaotong University Press, 2013. 